\title{
Exploitation of Petroleum Resources and the Challenges of Development of the Niger Delta Region of Nigeria
}

\author{
Dr Endurance Oriakhi. \\ School of law, Business and Social Science, Abertay University, United Kingdom.
}

\begin{abstract}
Nigeria is blessed with petroleum deposits, which are largely available in the Niger Delta region in Nigeria with abundant oil and gas resources. The development of the people of the Niger Delta has been on the front burner as it is believed that there is a need for economic transformation to ensure that the life of the people in the area should be able to achieve basic needs and standards of living. The conditions of life in the Niger Delta have been very weak, with the people not being able to meet their basic needs of life. There are challenges of low literacy level and poverty. The cases of oil pollutions continue to increase. The infrastructural development has been very poor. Employment opportunities are not readily available. Much is seen from the activities of militants. There is a need for reassessment of the development strides initiated by the Government and the oil companies operating in the Niger Delta for the good of the people of the Niger Delta.
\end{abstract}

Keywords: Oil and gas, Niger Delta, Development, Petroleum revenue, Pollution

DOI: $10.7176 / \mathrm{JLPG} / 112-19$

Publication date:August $31^{\text {st }} 2021$

\section{INTRODUCTION}

Even with the return of Nigeria to civil rule in 1999, the repression of the people of the Niger Delta continued (Human Rights Watch, 2002). The Niger Delta region of Nigeria is one of the regions that is rated among regions that have been extremely affected by the activities of oil exploitation (Sam and Zabbey, 2018). Ideally, the Niger Delta region of Nigeria should be entitled to development giving that it is the prolific region for the development generation of revenue which the country largely depends upon. When talking about developed countries in the world today, Nigeria does not fall into the list of the bottom ten. Usually, Nigeria is considered as one of the developing countries of the world today but has a lot of underdeveloped regions within her territory; one of these regions is the South-South region, popularly known as the Niger Delta region. The Niger Delta comprises of 9 oil-producing states (European Asylum Support Office, 2019); all six states of the South-south (Akwa Ibom, Cross River, Bayelsa, Edo, Delta and Rivers) and three other states from the two other southern regions (Ondo, Imo and Abia). Geographically, Ondo, Imo and Abia are excluded from the region, but politically, these states are included because they are oil-producing states and are also entitled to a certain percentage of the funds made from the production of oil (Banjoko, G., Mcardle, L., Musa, A. \& Yusuf, Y. Y., 2013:112).

Regulating the environment through the effective implementation of the laws and best practices have not been achieved in the Niger Delta (Albert et al., 2018). The States most affected by decadence in the environment are Delta, Bayelsa and Rivers States. Nwagbo (2017) has said that Nigeria is the largest producer of oil in West Africa, and as at the time he wrote this, the Niger Delta region produced 2 million barrels of oil per day. This region, comprising of minority ethnic groups, is responsible for the major source of the country's income - crude oil. Since the discovery of crude oil in Oloibiri, Bayelsa State, in 1956, there has been an influx of oil companies desirous of tapping into the massive wealth sitting under the region. This study examined the development in the Niger Delta, taking into account the initiative of the Government through the establishment of the Niger Delta Development Commission as an agency from projecting the development of the Niger Delta. It also examined the role of companies from the perspectives of oil-rich countries of the Niger Delta. How these initiatives of the Government and companies have fared were articulated in the study, reflecting on the need for the development of the oil-rich Niger Delta.

\section{THEORETICAL PERSPECTIVES}

The study of the crisis in the Niger Delta can be approached from the issues of development in the context of an oil-rich country. The term 'Development' signifies a positive change in the life and situation of anything, people, environment or community. It stands for an improvement in the standard of things, and in the Niger Delta, it has become a thing that forms the hope of every indigene and resident. Development in the world today is not limited to just a slight improvement in one or more areas; it encapsulates a lasting change that ensures that future generations have facilities and a healthy environment to be born into. Development in the world today has extended to ensuring that the enjoyment of the world facilities today does not cause damages that will hinder the enjoyment of the unborn generations. It is not just termed 'development' by World authorities but Sustainable development. Sustainable development, as seen by the United Nations, is a project that should carry everyone along, leaving no country or community behind and to ensure this, 17 certain goals were set. With a target of the 
year 2030, these goals include the eradication of poverty, hunger, poor health care systems, poor education systems, the provision of clean water and sanitation and action to protect the climate, amongst others (United Nations). The Report of the World Commission on Environment and Development (WCED) titled "Our Common Future", commonly known as the Brundtland Report, defines sustainable development as "development that meets the needs of the present without compromising the ability of future generations to meet their own needs" (1987: 41).

Sustainable development is thought to have certain core elements, without which it cannot be achieved. These elements are the Integration principle, Principle of Sustainable use, Principle of intra-generational equity (intra-generational justice) and inter-generational equity (inter-generational justice) (Wibisana, 2014:99). The Integration principle states that there is a relationship between the environment and the development of the world, and so the protection of the environment should be considered in the development process carried out by nations of the world. This principle stresses that the environment should not be treated in isolation from the development process but as an integral part of it. In the aspiration of the Nigerian Government to make more income from the mining of oil, it is important to note that the environment will be adversely affected in one way or the other. Thus, it is important to take sustainable development steps that will protect the environment and the rights of the people to a healthy land. The income of the nation should not be at the expense of a clean environment. The principle of sustainable use encourages the present generation to make use of natural resources with a mindset that other generations yet unborn will make use of it too. In Nigeria, for example, the constant mining of oil, which leads to the pollution of the land and water of the Niger Delta, jeopardises the chances of the future generation to a world with healthy and wealthy natural resources. The principle of intra-generational equity places a focus on meeting the needs of poor communities like a major part of the Niger Delta, such as Ozanogogo and Agbor. The final principle, Inter-generational equity, recognises the need to create a balance between the needs of this current generation and the needs of future generations. It is likened to a father leaving an inheritance for his children, which will help give them a good booster in their life struggles. It can also be likened to a trustee holding in trust the resources of this world and is expected to hand over the property held in trust in an intact state, using only that which is necessary to use.

Sustainable development is one key principle in environmental law that cannot be neglected, especially in the Niger Delta. Without it, there will be little or nothing for future generations to make use of. All of the outlined elements of sustainable development ought to be, but they are not applicable in the Niger Delta. As much as the Federal Government (who owns the primary responsibility of maintaining sustainable development) tries to establish a balance in the protection of the environment and the development of the nation through the mining of oil, certain circumstances have hindered these efforts. Key amongst these circumstances is corruption. It is a worm that has eaten deep into almost every sector of the country, including the maintenance of the Niger Delta and the welfare of its people. In the words of Ebiede "while environmental degradation caused by the oil industry limits the utilisation of the environment by the Niger Delta people, corruption by public officials in the Niger Delta region robs the local people of the developmental benefits accruable from oil revenues" (2011:139). There is an active relationship between the underdevelopment of the Niger Delta and the menace of corruption in the agency and officials committed to the development of the region (Osagie et al., 2010). The Government constantly visits and analyses the degradation of the Niger Delta region and assigns the task of maintaining the sanitation of the region to politically appointed officials. These officials, functioning under the Niger Delta Development Commission (NDDC), have been unable to fulfil the numerous promises of the Federal Government and have been accused of corruption and embezzlement of the funds meant for the growth of the region. These actions have made development in the region an impossible task such that maintaining sustainable development seems to be a dream that will take decades to accomplish.

\section{LITERATURE REVIEW}

There are series of literature on the discourse of the Niger Delta, most of which has focused on the crisis. Despite the huge oil reserves that Nigeria has and the promise of large funds coming from its production, Cyril Obi (2010:443) believes that "oil is more of a curse than a blessing in Nigeria". Agbiboa D. E. \& Maiangwa, B. (2012) believe that this view is based on the fact that the funds made from oil in Nigeria have been stashed away by the public officials up to the point of overflow, thus twisting the country's development and then impoverishing the people of the oil-rich region. They also think that the concept of corruption is fast becoming a trend in developing countries and has often been covered up by the unwillingness of academic writers to write about it and ascribe blame to the guilty ones. Similar to the World Bank's definition of corruption, Joseph Nye (1967: 419) defines corruption as "behaviour which deviates from the normal duties of a public role because of private-regarding (family, close private clique), pecuniary or status gains; or violates rules against the exercise of certain types of private-regarding influence". Corruption is not a concept that develops on its own; it is linked to the desires of people to make gains for themselves at the expense of others. This has been buttressed by Friedrich (1990: 15), who said that the pattern of corruption exists where a person in authority (specifically Government 
authority), charged with certain responsibilities, chooses to act contrary to the responsibilities expected of him in favour of another because of some sort of monetary or other reward provided by the latter. The result of unrestrained corrupt officials is the inability to fulfil the promises made to underdeveloped regions.

There are theories of ownership when it comes to the rights of citizens and the Government over mineral resources practised all over the world. The first theory is called Absolute Ownership. This theory states that ownership of land extends to the natural resources underneath the land and this right can be transferred or inherited. The Latin maxim quic quid plantatur, solo solo cedit meaning "whatever is affixed to the soil belongs to the soil", better explains this ownership theory (Okonkwo, 2017), and it is mostly practised in many states of the United States of America, including Texas. The second ownership theory is called the Qualified Ownership theory, wherein no one can claim ownership of mineral resources unless he has tapped into it and is in actual possession of the minerals. This theory basically states that whosoever has possession of the minerals in his hands rather than a vague claim of ownership of the minerals underground is the actual owner. The State of Pennsylvania in the United States of America practices this theory. The third theory is known as the NonOwnership theory, and the United States Legal department states it as:

A characterisation of oil and gas rights used in a minority of jurisdictions [in the United States].

This theory holds that the owner of a severed mineral interest does not have a present right to possess the oil and gas in place, but s/he has the right only to search for, develop, and produce it" (US Legal.com).

In other words, due to the fugacious nature of oil and gas, no one can claim ownership of what is contained underneath his land if it is tapped by another from a piece of land close to his. Whosoever searches for and taps into the resources is the owner of the discovered resources. This is prevalent in the State of Oklahoma in the United States of America.

The fourth theory of ownership is what operates in Nigeria. The Nigerian Constitution supports a citizen's ownership of moveable and immovable property in any part of the country. This is supported by the provision in section 43 of the 1999 Constitution that states that "Subject to the provisions of this Constitution, every citizen of Nigeria shall have the right to acquire and own immovable property anywhere in Nigeria." However, this right is not unlimited as there is an exception to the exercise of the right thereof. Section 44(3) of the Constitution states that:

Notwithstanding the foregoing provisions of this section, the entire property in and control of all minerals, mineral oils and natural gas in under or upon any land in Nigeria or in, under or upon the territorial waters and the Exclusive Economic Zone of Nigeria shall vest in the Government of the Federation and shall be managed in such manner as may be prescribed by the National Assembly.

Item 39 under the second schedule of the Exclusive Legislative List outlines these mineral and natural resources as "Mines and minerals, including oil fields, oil mining, geological surveys and natural gas". Section 1 of the Petroleum Act 1969 in Nigeria also supports this theory with the provision that "the entire ownership and control of all petroleum in, under, or upon any lands to which this section applies shall be vested in the state". What this means is that despite the ownership rights of an individual, he does not have the exclusive rights to all that is contained therein. All that qualifies as mineral and natural resources as stated under item 39 that is found on the land is exempted from being owned by an individual. The Government has the sole and primary rights to own and manage the same. This is the Domanial Ownership theory (Ekhator, 2016:45). This theory states that ownership of oil and gas is vested in a sovereign authority. It is the practised theory in Nigeria and the United Kingdom, the former colonial authority of Nigeria. The Supreme Court has also confirmed the exclusive ownership of oil and gas found offshore and onshore in the territory of the Federal Government of Nigeria in the case of Attorney-General of the Federation v. Attorney General of Abia State and 35. In this case, the 36 States of the Federation challenged the attempt by the Federal Government to deprive them of their revenue allocation as provided for in the 1999 Constitution.

The Nigerian Constitution of 1960, the very first constitution after the discovery of oil and the Nigerian Independence, provided that any region from which mineral resources were mined, including the Niger Delta region, was entitled to $50 \%$ of the total revenue gotten as royalties from the mining done in the region (1960 Nigerian Constitution, s. 134). This same allocation percentage was maintained in the 1963 Constitution (s. 140). In the present 1999 Constitution, the exclusive rights of oil and other mineral resources are vested in the Federal Government, and the revenue allocation payable by the Federal Government to the region has been reduced to $13 \%$ (s. 162). This has been considered as an unfair percentage allocated to a region that provides about $65 \%$ of the country's total revenue (NEITI, 2020).

THE CHALLENGES OF DEGRADATION AND LIVING CONDITIONS IN THE NIGER DELTA

The development of the people of the Niger Delta has been stalled by the crisis arising from oil and gas 
exploitation in the region. This consequently impacts the life and wellbeing of the people of the region. A report by Amnesty International has stated that "the Niger Delta is Africa's most important oil-producing region and one of the most polluted places on earth". With a record of constant oil spills, this report is not far from the truth. According to this report, Shell BP reported an oil spill of 17.5 million liters in 2011 while Eni (through its Nigerian subsidiary Nigerian Agip Oil Company) reported an oil spill of 4.1 million liters in 2014 (Amnesty International: 2018). Nwagbo (2017) reports that the major oil spills that have occurred in the Niger Delta region include a 1979 spill of 570,000 barrels of oil into the Forcados estuary in Delta State; a 1980 spill of 421,000 barrels of oil in Funiwa with the spill flowing into the ocean; and a 1983 spill of 5,000 barrels of oil in Oshika village. These spills not only polluted the aquatic and swamp forest environment but also destroyed large acres of mangrove forest and aquatic life in the neighbouring swamps. Oil pollution in the region is due to a number of reasons which include negligence by the oil companies, third party activity and mechanical failure (which can be properly managed by the oil companies if they cared to).

The water has been polluted as people cannot drink, fish or swim in the waters because of the polluted state. In many places, signboards are put up near streams and rivers to caution people against having contact with the water in order to avoid decadence in people's health. Often and again, the oil companies have blamed the leakages in their pipelines and the oil spills on oil thieves drilling into the pipes. However, this report has been debunked by Amnesty International (2018), who, through the help of decoders, noted that several of the pipes have holes, through which oil leaked, on the underside of the pipe buried deep in the ground. If an oil thief were to have drilled the holes, he would have done so on the side of the pipe close to the surface of the ground and not on the side buried underground. This is just one of the tactics of the oil companies to escape the need to face legal actions and pay compensation.

Water and soil pollution is not the only challenge of the Niger Delta oil activities. The air the people breathe has also been subject to this pollution. The region is not just rich in oil; it is also rich in gas. At the moment, the oil companies are only invested in mining the oil with little interest in the wealth of gas available therein. While the oil is being mined and processed, the oil companies consider the gas as waste and flare it into the air. Thus, the oil is not healthy for human consumption. Emam (2015:532) defines gas flaring as "a combustion device to burn associated, unwanted or excess gases and liquids released during normal or unplanned over-pressuring operation in many industrial processes, such as oil-gas extraction, refineries, chemical plants, coal industry and landfills". It is also the main source of greenhouse gases emissions. Ana (2011) wrote that at $19.79 \%$ globally and $46 \%$ in Africa, Nigeria holds the highest record of gas flaring for every ton of oil produced.

In 2005, an indigene of the region, Jonah Gbemre, instituted an action against Shell to restrict it from continuing in the acts of gas flaring. The court, while awarding judgment to the plaintiff, stated that gas flaring in a community where people live is unconstitutional and a violation of the right to life and dignity of human persons. The court further declared that gas flaring leads to a rise in air poisons and environmental pollution, the results of which are cancer, asthma, respiratory illnesses, painful breathing and premature death, and so the plaintiff and the other residents of his community had the right to a clean and healthy environment without pollutants caused by the defendants in the air (Gbemre v. SPDC Ltd \& Ors).

One interactive topic from the Niger Delta region is the Ogoni cleanup. It was commissioned in 2016 by the Nigerian President as a response to one of the recommendations of the United Nations Environmental Programme (UNEP) report, and it has been going on for years. It is difficult to imagine how long it took for that amount of pollution to have slipped into the environment. A report titled "No Cleanup, No Justice" (2020) made by certain environmental groups has revealed that the United Nations Environmental Programme (UNEP) recommended certain cleanup measures in 2011 and almost ten years after the recommendations, the cleanup measures have begun in only $11 \%$ of the affected Niger Delta region. This report estimates that Shell alone has spilt about nine to thirteen million barrels of crude oil since it began operations in 1958 and that 31 million US dollars funding provided in 2018 has not been publicly accounted for. In this same report, the words of Godwin Ojo of the Environmental Rights Action/Friends of the Earth Nigeria expresses the agony of the Ogoni people in just the right words - "After nine years of promises without proper action and decades of pollution, the people of Ogoniland are not only sick of dirty drinking water, oil-contaminated fish and toxic fumes, they are sick of waiting for justice; they are dying by the day" (McGuire, 2020). Late Ken Saro Wiwa, an environmentalist and poet, who was killed by the Nigerian Government, lamented that the extinction of the Niger Delta was imminent with the wage of what he called an ecological war on the region (Ajodo-Adebanjoko, 2017).

An incident happened in Koko, Delta State in the Niger Delta region in 1988 (Ogbodo, 2009). Tons of toxic waste was dumped in the compound of a man, Sunday Nana, by an Italian company under the guise that they were raw materials, and a storage fee was paid to him for them to remain in his compound. Residents of the town suffered several ailments, including nausea, paralysis, premature births, and Sunday, Nana himself died of throat cancer. This incident has come to be known as the 1988 Koko incident. And it was what led to an awakening of the Nigerian Government on the need to have Environmental Laws protecting the country's environment from pollution. Amongst these laws were the Federal Environmental Protection Agency (FEPA), 1988, Harmful 
Waste (Special Criminal Provisions) Act, 1988 and Environmental Impact Assessment Act (EIA), 1993. As the years rolled by, several other laws were made including the National Oil Spill and Detection Agency Establishment Act (NOSDRA), 2006 and the National Environmental Standards and Regulations Enforcement Agency (Establishment) Act (NESREA) 2007. The NESREA Act defines the environment as including water, air, land, all plants, human beings and animals living therein and the inter-relationships which exist amongst them (s. 37). These environmental laws have taken cognisance of the fact that activities of oil mining have a high tendency of polluting the land, air and water of the environment and thus made provisions that seek to constrain the excesses of oil companies that are likely to harm the environment. Without these laws, the pollution of the region would have been much more than is being recorded now. However, despite the pollution restraining provisions with penalties attached, oil companies are still negligent in their oil mining activities.

The National Oil Spill and Detection Agency (NOSDRA) Act, 2006 provides that oil companies are expected to visit and assess leakage sites and report to the National Oil Spill and Detection Agency within 24 hours or be fined $\$ 2,000,000$ (one million naira) for each day of default (s.6(2)). The act also requires oil companies to clean up such leakage sites within two weeks of the leakage occurrence or be fined a penalty not more than $¥ 5,000,000$ or an imprisonment term not more than two years (6(3)). However, reports by Amnesty International have stated that oil companies visit some leakage sites months after the first report. At a time, Eni took 430 days to visit an oil spill site in Bayelsa, during which time oil had spilt into nearby rivers and contaminated them, making it impossible for the people to drink and wash with the water fetched from it (ibid). One can only imagine the level of pollution that could have been caused in that period of over a year.

Despite the oil spills recklessly allowed by oil companies, a ridiculous amount of compensation are offered to the affected communities. In 2008 and 2009, there were two oil spills in Bodo, a town where the residents made their livelihoods from fishing. The oil spills killed most of the marine life and, as a result, terminated the livelihoods of the residents of the town. Shell, the oil company responsible for the oil spills, compensated the entire community with a ridiculous amount of $\$ 4000$. Amnesty International assisted the community in seeking legal action, and the result was an out of court settlement of 55 million US dollars in compensation (Amnesty International)

Apart from national laws on the protection of the environment, there are also international laws with a stand against oil pollution. These laws include the International Convention for the Prevention of Pollution from Ships 1973 (MARPOL 73) and the International Convention on Oil Pollution, Preparedness, Response and Cooperation (OPRC) 1990.

The effects of these oil spills and the pollution of the Niger Delta has made the people of the region one of the poorest of the country. The Niger Delta region contains one of the largest mangroves and freshwater swamp forests in the world, with the people's predominant occupation being fishing and farming. Their main sources of livelihood - fishing and farming - have constantly been subjected to ruin and contamination by the activities of oil mining on their land (Solomon, George-West, Alalibo, 2017).

These situations of pollution and poverty and a lack of positive response to their agitations, and a request for a good standard of living have led many of the youths into militancy. These militant youths are known as Niger Delta militants and have been wreaking havoc on the pipelines and oil fields of oil companies in the region long before Boko Haram terrorists and herdsmen began their deadly activities.

Since oil was discovered in the Niger Delta and the resultant adverse effects that have been experienced by the people, the distress cries of the people seem to have fallen on deaf ears of the Government. So, agitated youths chose to come together to form militant groups that would fight for the rights of the Niger Delta people. The objectives of their operation are to have local control of the oil rather than a federal control, and thus they seek autonomy of the region. These militants live in creeks, and their modes of operations involve violent attacks on the fields and infrastructure of oil companies and regular kidnappings of their expatriates. Since the last century, several militant groups have arisen; prominent amongst them are the Niger Delta People's Volunteer Force (NDPVF), the Movement for the Emancipation of the Niger Delta (MEND) and the Niger Delta Avengers (NDA). The operations of these militant groups have led to a reduction in the turnover of income made from the production of oil in the region. In 2017, the Government lost 1.8 billion naira on a daily basis (AjodoAdebanjoko, 2017). The NDPVF and MEND groups have experienced a decline in operations, especially since the introduction of the amnesty programme in 2009.

Prior to 2009, the security situation in the Niger Delta was so weak that even the residents were scared for their lives. The activities of the militants made their presence hard to ignore by the Government, oil companies and the citizens. In 2009, the President Musa Yar'adua led administration introduced a call for amnesty that involved the surrendering of arms by the militants, cash payments to the former militants in a bid to calm their raging nerves as well as a training organised by the Government. This was seen as a win-win solution for the Government and the militants. Several militants surrendered their arms and were allowed into the society as free men; and for a few years afterwards, the region experienced peace and calm. However, it seems like the calm is expiring as the Niger Delta Avengers awoken the fight for control and have resumed the destruction of oil fields 
and infrastructures. This reawakening is large because the current administration breached the amnesty deal (BBC, 2016). Unlike the peaceful initiative introduced in 2009, the present Government has responded to this fresh militancy by constituting a military operation with the code name "operation crocodile smiles" (AjodoAdebanjoko, 2017). This is not the best of recommended measures as it will only fuel the violence the more.

The words of Modupe Funmilayo \& Modupe Adu (2014:32) about the activities of the militants cannot be ignored; "A society where insurgency becomes relevant to achieve a political objective is on its way to crisis". So, rather than allow the people of the region to demand their development rights through the use of arms and violence, the Government and all concerned stakeholders should meet their rightful demands in order to avert a crisis.

\section{THE ROLE OF OIL CORPORATIONS}

All over the world, multinational companies have started getting involved in Corporate Social Responsibility (Banjoko, G., Mcardle, L., Musa, A. \& Yusuf, Y. Y., 2013:111). Banjoko, G. et al. (2013) have defined Corporate Social Responsibility as "the ability of the organisation to embrace practices that address the wellbeing of their workforce, the community and the society". These practices are those that help develop the society which they take from; without the patronage and accommodation of the host community, a company may not survive the rigours of growth and competition in business. This social responsibility includes anything and everything that improves the standard of living of the community residents. Section 14 (2)(b) of the Niger Delta Development Commission (Establishment) Act provides that all oil companies are obligated to pay a sum equal to 3 per cent of their total annual budget as their contribution to the Niger Delta Development.

Money made in the Niger Delta does not go into the coffers of the Government alone; the multinational Oil companies, primarily involved in the process of oil mining, also make a huge profit amounting to billions of dollars yearly. So, it is necessary that they also get involved in the development of the region from which they make a major part of their wealth. Apart from this responsibility, it is normal to find companies get involved in corporate social responsibility tasks as a way of giving back to the society that contributes to the growth of their businesses. Multinationals in Nigeria have built hospitals, pipe-borne water, schools, amongst others, as CSR initiatives; however, oil companies in Nigeria have not been actively involved in Corporate Social Responsibility as is expected (Ekhator, E. O., 2014). The CSR that these companies have done to add to the development of the region is belittled with the constant acts of pollution by these same companies. If the oil companies reduce their acts of pollution to the barest minimum, it is enough corporate social responsibility to the Niger Delta people.

\section{DEVELOPMENT IN THE NIGER DELTA: A POSSIBILITY?}

The oil exploration of these companies leave an environment unfit for human living; an environment riddled with polluted waters, polluted lands and a polluted atmosphere mostly as a result of gas flaring. The resultant effect of this pollution is the poverty of the inhabitants, who are mostly crop and fish farmers. If the ownership of the natural resources of the region was vested in the owners of the land, they would have been able to claim and enforce stricter measures in ensuring that the oil companies clean up the pollutants they create, but in Nigeria, the authority and ownership of all Natural resources are vested in the Federal Government (Nigerian Constitution 1999, s. 44(3)), and it has the responsibility of ensuring a sane and clean environment in the areas where there are activities of oil exploration. Unfortunately, even though there have been efforts by the Government to live up to this responsibility, there has been little or no change. The affected people complain, and with the little funds at their disposal, they are unable to take legal actions to enforce their rights to a clean and healthy environment. The African Charter on Human and Peoples' Rights 1986 provides that everyone has "the right to a satisfactory environment favourable to their development" (Art. 24). Nigeria, as a party to the African Charter on Human and Peoples' Rights, has the responsibility of ensuring that the rights of the Niger Delta people to a satisfactory and clean environment is protected.

So, in an effort to curb the menace of pollution and to take care of the welfare of the people of the Niger Delta, the Niger Delta Development Commission (NDDC) was established in 2000 by former President Olusegun Obasanjo. The NDDC has the responsibility of dealing with issues (especially those that affect the ecology) that arise from the oil mining activities in the region and all related matters in the Niger Delta. The NDDC also has the responsibility of taking measures that will help sustainable development in the region. The NDDC has also been involved in creating scholarship opportunities for Niger Delta indigenes to study in universities abroad (The Guardian, 2015). This is one of the means of compensation for the destruction they have faced and suffered and the impoverishment that has arisen as a result of it. However, the financial provisions made available towards the fulfilment of this responsibility has constantly been the subject of embezzlement, and so, with the questionable characters of the NDDC officials in the light of widespread corruption in the country, the promise of development that the Niger Delta people look forward to has remained a mere promise with little or no hope of a positive change.

With the situation of things in the Niger Delta at the moment, especially the corruption that has riddled the 
Niger Delta Development Commission, it would seem like the Niger Delta people are still in the dream phase and are yet to get close to the point where they can fully see the reality of development. If an average Niger Delta man is asked if the development of the region is a possibility or a promise, the latter is likely to be his answer. If reasonable development is still a dream, it is difficult to imagine what to call sustainable development with the rate of pollution and environmental defilement rampant in the region today. Chinago, A. B. (2017) said that the type of development in Nigeria is not environment friendly. The questionable character of officials placed in charge of the NDDC and the embezzlement of the funds put in their care makes it almost impossible for sustainable development to be actualised in the region. The Niger Delta Development Commission (NDDC) was established by the Niger Delta Development Commission (NDDC) Act, 2000, with the primary purpose of the act being:

Establish a new Commission with a re-organised management and administrative structure for more effectiveness and for the use of the sums received from the allocation of the Federation Account for tackling ecological problems which arise from the exploration of oil minerals in the Niger Delta area and for connected purposes.

The membership of the NDDC governing board consists of one representative from each of the oilproducing states, three representatives of non-oil producing states, a representative of the oil companies, a representative of the Ministry of finance, a representative of the Ministry of Environment, two executive directors, a managing director and a chairman (s. 2). The functions of the commission are outlined under section 7 (1) (a-j) of the NDDC Act as follows:

7. (1) The Commission shall-

(a) formulate policies and guidelines for the development of the Niger- Delta area,

(b) conceive, plan and implement, in accordance with set rules and regulations, projects and programmes for the sustainable development of the Niger-Delta area in the field of transportation, including roads, jetties and waterways, health, education, employment, industrialisation, agriculture and fisheries, housing and urban development, water supply, electricity and telecommunications;

(c) cause the Niger-Delta area to be surveyed in order to ascertain measures which are necessary to promote its physical and socio-economic development,

(d) prepare master plans and schemes designed to promote the physical development of the Niger-Delta area and the estimates of the costs of implementing such master plans and schemes;

(e) implement all the measures approved for the development of the Niger- Delta area by the Federal Government and the member states of the commission;

(f) identify factors inhibiting the development of the Niger-Delta area and assist the member States in the formulation and implementation of policies to ensure sound and efficient management of the resources of the Niger-Delta area,

(g) assess and report on any project being funded or carried out in the Niger-Delta area by oil and gas producing companies and any other company including non-governmental organisations and ensure that funds released for such projects are properly utilised;

(h) tackle ecological and environmental problems that arise from the exploration of oil minerals in the Niger-Delta area and advise the Federal Government and the member States on the prevention and control of oil spillages, gas flaring and environmental pollution-,

(i) liaise with the various oil mineral and gas prospecting and producing companies on all matters of pollution prevention and control.

(j) execute such other works and perform such other functions which, in the opinion of the commission, are required for the sustainable development of the Niger- Delta area and its peoples.

With such a detailed list of duties and responsibilities and regular provision of funds, one would think that it should not be an uphill task for the NDDC to function as is expected of them. However, the reverse has been the case with several allegations of corruption and funds embezzlement; we need not wonder why the Niger Delta has been banking on unfulfilled promises for two decades after the establishment of the NDDC. In July 2020, a major part of the nation was glued to their television set screens as the National Assembly set up a panel to investigate the misappropriation of 40 billion naira by the NDDC. Several revelations of misappropriation were made, with many key officials been implicated in the allegations. Kemebradikumo Pondei, a professor of microbiology and the former acting Managing Director of NDDC, collapsed while he was being questioned by the panel (Oamen, 2020). Many have said that he lost consciousness and collapsed as he could not think of another way of escape from the several questions that could have exposed the thick corruption that dwelled within the commission. As a result of his inability to respond to the questioning by the panel and his inability to account for the funds, the President, Muhammadu Buhari terminated his appointment as acting MD and 
appointed another in his place.

Corruption is not so difficult to identify and define; it has been defined by the World Bank as an abuse of public office and opportunities for private benefits and gains (Wei, 1999:2). About 70\% of the Niger Delta people survive on less than $\$ 1$ per day (Tokpo, 2012:45). This is a region whose people would have been the richest if Nigeria practised the Absolute ownership theory. The poverty of the region is not detached from the corruption in the NDDC, and if the worm of corruption is not quickly found and destroyed, the situation of the Niger Delta people is far from being better.

As noted earlier, much is expected to be done for the people of the Niger Delta to address the problem of the region. The problem has been ongoing. According to the Human Rights Watch (2002):

The presence of the oil companies in the Niger Delta exacerbates communal tensions of the type seen across Nigeria. The weakness of conflict resolution structures - whether the courts, responsible elected and appointed state officials, or the law enforcement agencies-means that many disputes in Nigeria are settled violently that could have been resolved through peaceful means.

The above situation has continued to remain as the state of affairs in the Niger Delta. There is a dire need to set a mechanism that will address the challenges. The peaceful coexistence of the people of the Niger Delta has an impact on the socio-economic wellbeing of the nation.

\section{CONCLUSIONS AND RECOMMENDATIONS}

The exploration and production activities in the Niger Delta, as well as the natural resources governance regime in Nigeria, has not been favourable to the people of the Niger Delta generally. The people of the Niger Delta are entitled to the dividend of exploration and production of the resources in the region. It is expedient that much will need to be done to ensure that our initiatives to actualise the development of the people of the Niger Delta are provided for and are met accordingly. The level of development has been largely retarded. Addressing the problems in the Niger Delta will require taking into account the promotion of social justice (Ako, 2009). After analysing the situation in the Niger Delta, one question that one would most likely ask is; Is the development still visible and something to expect in the nearest future or is it still a mere promise? For a win-win solution for the Niger Delta people, the Government and the oil companies, certain measures have to be put in place. Some of these are a higher allocation in the national budget targeted at environmental sanitation (Solomon, L., GeorgeWest, O. \& Alalibo, I.K., 2017). The oil and gas resources in the Niger Delta has brought about hardship for the people giving the continuity of pollutions.

Environmental sanitation does not seem to be of prime interest to the Government of Nigeria, and so environmental pollution has been indirectly allowed. Supposing there is a reasonable increase in the funds created for this purpose in the annual budget, there will be available facilities to properly prevent pollution and punish offenders. While increasing the funds for environmental sanitation, the derivation percentage for this region should also be increased. This will enable the respective states to have access to more funds to develop the dilapidated condition of the region.

It is unarguable that the Federal Government owns exclusive rights to oil and all minerals found in Nigeria, but the States Government are closer to the region and can better utilise the funds derived therefrom for the benefits of the region. Secondly, the Ministry of Niger Delta Affairs and all agencies under it should ensure that oil companies are involved in functional corporate social responsibility. Mere promises should not just be made; they should be followed up by reasonable actions. Thirdly, the institutional framework governing the production of oil and its stakeholders should be strengthened to be at par with international standards. Stricter penalties should be enforced, and possibly a special division should be created in the Nigerian courts to handle and preside over matters arising from the degradation of the Niger Delta Development. This will encourage speedy measures in enforcing the rights of the people to a sane and healthy environment. Companies must be made to undergo environmental impact assessments with strict penalties for failure to do so, and the recommendations of the assessment must be strictly followed.

\section{REFERENCES}

Agbiboa, D. E. \& Maiangwa, B. (2012). Corruption in the Underdevelopmentof the Niger Delta in Nigeria. The Journal of Pan African Studies, 5(8), 108-132.

African Charter on Human and Peoples' Rights 1986.

Ajodo-Adebanjoko, A. (2017). Towards ending conflict and insecurity in the Niger Delta region. Retrieved December 23, 2020 from https://www.accord.org.za/ajcr-issues/towards-ending-conflict-insecurity-nigerdelta-region/

Ako R, Okonmah P and Ogunleye T, (2009). The Niger Delta Crisis: A Social Justice Approach to the Analysis of Two Conflict Eras Journal of African Development 11(2), 105-122.

Amnesty International. (2018). Niger Delta Negligence. Retrieved December 20, 2020 from 
https://www.amnesty.org/en/latest/news/2018/03/niger-delta-oil-spills-decoders /

Amnesty International, Friends of the Earth Europe, Friends of the Earth Netherlands/ Milieudefensie, Friends of the Earth Nigeria/ Environmental Rights Action. (2020). No Cleanup, No Justice: an Evaluation of the Implementation of UNEP's Environmental Assessment of Ogoniland, Nine Years On, 1-40

Ana, G. A. (2011). Air pollution in the Niger Delta area: scope, challenges and remedies. The Impact of Air Pollution on Health, Economy, Environment and Agricultural Sources.

Attorney-General of the Federation v. Attorney-General of Abia State and 35 Others (2001) 11 NWLR 689.

Banjoko, G., Mcardle, L., Musa, A. \& Yusuf, Y. Y. (2013). Corporate social responsibility in Nigeria's oil and gas industry: The perspective of the industry. International Journal of Process Management and Benchmarking, 3(2), $101-135$.

BBC News. (2016, August 2). Nigeria to resume payments to oil militants in Niger Delta. Retrieved December 23, 2020, from https://www.bbc.com/news/world-africa-36953269

Bello, N. Over 2000 Niger Delta Youths in universities abroad on amnesty scholarship, The Guardian. Retrieved December 23, 2020, from https://m.guardian.ng/appointments/c29-appointments/over-2000-niger-deltayouths-in-universities-abroad-on-amnesty-scholarship/

Brundtland, G. (Ed). (1987). Our Common Future: Report of the World Commission on Environment and Development. Oxford University Press.

Chinago, A. B. (2017). Sustainable development in fragile Niger delta region: A task for environmentalists. International Journal of Development and Sustainability, 6(10), 1293-1304.

Sam K and Zabbey N. (2018). Contaminated land and wetland remediation in Nigeria: opportunities for sustainable livelihood creation, Sci. Total Environ., 639, 1560-1573.

The Constitution of the Federation of Nigeria 1960

The Constitution of the Federal Republic of Nigeria 1963

The Constitution of the Federal Republic of Nigeria 1979

The Constitution of the Federal Republic of Nigeria 1999

Ebiede, T. M. (2011). Conflict Drivers: Environmental Degradation and corruption in the Niger Delta Region. African Conflict and Peacebuilding Review, 1(1), 139-151.

Ekhator, E. O. (2014). Corporate social responsibility and Chinese oil multinationals in the oil and gas industry of Nigeria: an appraisal. Cadernos De Estudos Africanos, 28, 119-140. Retrieved December 26, 2020 from http://journals.openedition.org/cea/1704, DOI: https://doi.org/10.4000/cea.1704

Ekhator, E. O. (2016). Public Regulation of the Oil and Gas Industry in Nigeria: An Evaluation. Annual Survey of International \& Comparative Law, 21(1), 43-91.

Emam, E. A. (2015). Gas Flaring in Industry: An Overview. Petroleum \& Coal 57(5), 532-555.

European Asylum Support Office. (2019). Militant groups in the Niger Delta. Retrieved December 23, 2020 from https://www.easo.europa.eu/country-guidance-nigeria/122-militant-groups-niger-delta

Friedrich C. J. (1990). (as cited in Agbiboa, D. E. \& Maiangwa, B. (2012). corruption in the Underdevelopment of the Niger Delta in Nigeria. The Journal of Pan African Studies, 5(8), 108-132.)

Gbemre v. SPDC Ltd \& Ors (FHC/B/CS/53/05).

McGuire, J. Common dreams, Niger delta still waiting for big oil to clean up devastating pollution. Ecowatch. Retrieved December 22, 2020, from https:/www-ecowatch.com/niger.delta-pollution-2646218738.html

Modupe A. \& Modupe F. (2014). Niger Delta development in a corruption-ridden society: Importance of insurgency. Global Journal of Human Social Science in Interdisciplinary 14(2), 32-41.

National Environmental Standards and Regulations Enforcement Agency (Establishment) Act (NESREA) 2007

National Oil Spill and Detection Agency (NOSDRA) Act, 2006

Niger Delta Development Commission (Establishment) Act

NEITI (Nigeria Extractive Industries Transparency Initiative). (2020). Tax and Legal framework. Retrieved December 18, 2020, from https://eiti.org/es/implementing_country/32

Nwagbo, G. (November 2017). Oil Pollution in the Niger Delta, Nov. 2017, coursework for PH240, Stanford University, 2017

Nye, J. (1967). (as cited in Agbiboa, D. E. \& Maiangwa, B. (2012). corruption in the Underdevelopment of the Niger Delta in Nigeria. The Journal of Pan African Studies, 5(8), 108-132.)

Oamen, S. (2020, July). 11 things to know about NDDC Acting MD, Pondei. The Nation. Retrieved December 23, 2020, from https://thenationonlineng.net/11-things-to-know-about-nddc-acting-md-pondei/

Obi, C. (as cited in Agbiboa, D. E. \& Maiangwa, B. (2012). corruption in the Underdevelopment of the Niger Delta in Nigeria. The Journal of Pan African Studies, 5(8), 108-132.)

Ogbodo, G. S. Environmental Protection in Nigeria: Two Decades after the Koko Incident. Annual Survey of International \& Comparative Law, 15(1).

Okonkwo T. (2017). Ownership and Control of Natural Resources under the Nigerian Constitution 1999 and Its Implications for Environmental Law and Practice. International Law Research 6(1), 162-184. 
Osagie J, Akinpelu, F, Adegoke F., Ezeani S, (2010). Causes of Conflicts in the Niger Delta Region of Nigeria as Expressed by the Youth in Delta State, Procedia Social and Behavioral Sciences, 5, 82-89.

Oshienemen N.A, Amaratunga D., and Haigh R.P. (2018). Environmental Policies within the Context of Compensation for Oil Spill Disaster Impacts: A Literature Synthesis Author links open overlay panel, Procedia Engineering, 212, 1179-1186.

Petroleum Act, P10 Laws of the Federation of Nigeria 2004, Vol. 13

Solomon, L., George-West, O, \& Alalibo, I.K. (2017). Environmental pollution in the Niger delta and consequential challenges to the sustainable development of the region: The role of an individual. Researcher, 9(8), 10-15.

Tokpo C. E. (2012). Petro-politics, corruption and poverty in Nigeria: A case study of Bayelsa State. M.Sc Thesis, University of Port Harcourt, p. 45.

United Nations. Envision2030: 17 goals to transform the world for persons with disabilities. Retrieved December 19, 2020, at https://www.un.org/development/desa/disabilities/envision2030.html

US Legal. Non-Ownership Theory Law and Legal Definition. Retrieved December 17, 2020, from http://www.definitions.uslegal.com

Wei, S. (2017). Corruption in economic development: beneficial grease, minor annoyance, or major obstacle? Policy Research Working Paper, 1-30.

Wibisana, A.G. (2014). The elements of sustainable development: Principles of integration and sustainable utilisation. Mimbar Hukum, 26(1), 98-111. 